\title{
Politi og arkitekters forebyggingslogikker: Forståelser av kriminalitetsforebyggende arbeid i offentlige rom ${ }^{1}$
}

\author{
Marina Hiller Foshaugen, Førstekonsulent, Institutt for kriminologi \\ og rettssosiologi, Universitetet i Oslo
}

\begin{abstract}
This article focuses on crime prevention through architecture, environmental design and other situational modifications to public space. Today's crime control is characterized by a continuously expanding focus on prevention and the proliferation of new contributions to preventive work. In the literature, the situational crime prevention approach is an acknowledged and well-known field in which strategies have been used to reduce crime in public spaces for decades. In Norway, however, this remains an area of crime prevention with little empirical data. The current study therefore attempts to fill this gap in Norwegian research. Based on interviews with architects and police personnel, the article explores these actors interpret and understand prevention through architecture, environment and physical design. The main aim is to examine approaches to crime prevention in public spaces in regards to safety, security, risk and social control.
\end{abstract}

\section{Keywords}

crime prevention, public space, architects, policing

kriminalitetsforebygging, offentlige rom, arkitekter, politi

\section{Innledning ${ }^{2}$}

De siste årene har kriminalitetskontrollen vært preget av et stort fokus på forebygging (Garland, 2001; Zedner, 2007). Parallelt med et økt fokus på forebyggende aktiviteter, øker dessuten antall bidragsytere til kriminalitetsforebyggende arbeid (Ericson \& Haggerty, 1996; Rowe, 2008; Aas, mfl., 2010; van Steden, 2018). For mange regnes politiet som en åpenbar aktør på feltet, og enkelte hev-

1. Title in English: Legal and architectural approaches to prevention: understanding crime prevention in public spaces

2. Takk til Martin Nøklebergog de anonyme fagfellene for gode og konstruktive tilbakemeldinger. 
der til og med at politiet må være involvert for at noe skal kunne havne i kategorien forebyggende arbeid (Egge \& Barland, 2007: 159; Bjørgo, 2011). I praksis er bildet mer nyansert, da det finnes flere offentlige, private og frivillige aktører, som utfører arbeid med formål om at det skal ha en forebyggende effekt (Wakefield, 2003; Strudwick mfl., 2017; van Steden, 2018. Privat sikkerhetsindustri er gjerne synlig i privateide offentlige rom som kjøpesentre, helsevesenet jobber for å bekjempe og forebygge rusavhengighet, mens natteravnene som frivillig organisasjon holder seg tilgjengelig i gatebildet på kveldstid for å skape trygghet (Aas, mfl., 2010; Lundeberg \& Mjåland, 2017). Slike bidrag illustrerer at ulike kontekster avgjør hvem som kan anses som forebygger av kriminalitet.

I sammenheng med et økt fokus på forebyggende arbeid, synliggjøres dessuten ulike modeller for kriminalitetsforebygging. En tungtveiende trend har vært den situasjonelle logikken, som siden 1980-tallet har preget feltet (Clarke, 1980; Crowe, 2000; Garland, 2001; Gundhus, 2014). Konseptet fremhever hvordan fysisk utforming og ulike kontrollmetoder kan ha noe å si for et potensielt kriminalitetsnivå i fysiske områder (ibid.). På bakgrunn av dette kan man argumentere for at arkitektenes arbeid kan regnes som forebyggende, med tanke på at arkitektur, utformingen av bygninger og fysisk design er med på å legge grunnlaget for aktiviteten som foregår i det aktuelle området (Foucault, 1977-78; Carr mfl., 1992; Hvattum, 2015). Når man i tråd med dette ser at arkitektoniske løsninger kan ha noe å si for kriminalitetsnivået, vil de som jobber med arkitektur og planlegging, i hovedsak arkitekter, anses som bidragsytere. Til tross for at politiet har hatt en lenger forebyggingstradisjon enn arkitektene, kan sistnevnte yrkesaktører likevel være involvert i forebyggende oppgaver fordi de organiserer omgivelsene potensiell kriminalitet oppstår i. Politiet blir på en annen side en naturlig aktør på bakgrunn av at de håndterer kriminaliteten, både i forkant og etterkant.

Tidligere studier har gjerne fokusert på effekten av ulike forebyggende tiltak, og det er utviklet flere teoretiske bidrag som fokuserer på det eksterne miljøet rundt potensielle kriminelle (se for eksempel Jacobs 1962; Newman, 1972; Cohen \& Felson, 1979; Clarke, 1980; Armitage 2013). Det finnes derimot få empiriske studier som retter fokuset på aktørene som er involvert i slike arbeidsoppgaver, og enda færre som undersøker både arkitekters og politiets rolle på feltet. Denne artikkelen sikter inn mot å fylle det tilsynelatende gapet som eksisterer i litteraturen ved å belyse hvilke logikker som er fremtredende blant arkitekter og norsk politi ved deres kriminalitetsforebyggende arbeid i offentlige rom, gjennom arkitektur, design, fysisk utforming og andre situasjonelle tiltak.

Det å inkludere arkitektene i en slik studie bidrar til å belyse utvidelsen av polisiære aktører, med tanke på at yrkesgruppen kan anses som en mindre tradisjo- 
nell bidragsyter i det forebyggende arbeidet. Artikkelen viser hvordan forståelser av forebyggingstiltak gjennom arkitektur, design og situasjonelle tiltak er svært nyanserte, men at de likevel har et felles forankringspunkt og mål aktørene imellom.

Artikkelen er delt opp i fire deler, henholdsvis teoretisk kontekst, metode, analyse og diskusjon. Første del viser til tidligere forskning og det teoretiske rammeverket, som er bakgrunnen for studien. Funnene er basert på kvalitative data, og $\mathrm{i}$ metodedelen redegjøres det for datainnsamling og empiri. I hoveddelen vil funnene presenteres gjennom analyse og diskusjon, som igjen tar utgangspunkt $\mathrm{i}$ empirien og det teoretiske rammeverket.

\section{Kontekst - arkitektur og fysisk planlegging som forebyggingarena i Norge}

Forebyggingsfeltet er stort og komplekst, og det finnes mange ulike måter å forebygge på. I internasjonal sammenheng er Crime Prevention Through Environmental Design (CPTED) en anerkjent forebyggingsmetode, som inneholder strategier som benyttes i planleggings- og utbyggingsfaser av områder som eksempelvis byrom og nabolag. På et overordnet nivå bygger CPTED på en forestilling om å hindre et potensielt lovbrudd, fremfor selve lovbryteren. Dette med tanke på at modellen sikter på å tilrettelegge omgivelsene på en måte som gjør at sannsynligheten for kriminalitet minsker (Crowe, 2000; Cozens, 2002; Colquhoun, 2004; Armitage \& Monchuk, 2017).

I Norge har man utviklet retningslinjer i tråd med CPTED. I en periode forsøkte det kriminalitetsforebyggende rådet $(\mathrm{KRÅD})^{3}$ å rette kriminalitetsforebyggende tiltak mot eiendom og fysisk planlegging (Gundhus, 2014: 186). Som et resultat av et slikt fokus ble det blant annet gitt ut en veileder, som angir retningslinjer for planlegging av trygge områder (Unstad \& Christophersen, 1999). Veilederen er ment å gi en pekepinn på tiltak man bør vurdere å bruke i utbyggingsprosesser, men planleggere er ikke lovpålagt å følge dem. Til tross for dette finnes det likevel formelle bestemmelser som legger føringer for kriminalitetsforebyggende arbeid ved fysisk planlegging.

Plan- og bygningsloven ble endret i 2011, og etter at loven trådte i kraft skal arkitektene formelt sett arbeide forebyggende. Dette med tanke på at lovverket pålegger arkitekter, utbyggere og kommuner å arbeide kriminalitetsforebyggende i sine planleggingsprosesser (jf. Plan- og bygningsloven $\S 3-1$ bokstav f). Denne

3. KRÅD ble lagt ned i 2015 og erstattet med Kompetansesenter for kriminalitetsforebygging (Regjeringen, 2015). 
lovgivningen kan dessuten påvirke politiets rolle på feltet, da det hevdes at politiet har blitt mer involvert i kommunenes utbyggingsplaner enn det de har vært tidligere (Lie, 2011: 284). Med dette som utgangspunkt kan forebygging på dette området fremstå som relativt nytt for begge yrkesgrupper, da politiet ikke har hatt stort ansvar på denne arenaen tidligere, samtidig som kriminalitetsforebygging ikke er noe majoriteten av arkitekter forholder seg til.

\section{Et policing-perspektiv på forebygging - polisiær virksomhet og arbeid}

Til tross for at arkitektur og utforming har blitt anerkjent som verktøy til kriminalitetsforebyggende arbeid i lang tid, har ikke nødvendigvis arkitektene vært kjent som bidragsytere til denne form for arbeid. Dette er et kjent fenomen på forskningsfeltet, da policing, eller polisiær virksomhet, ofte assosieres med politiet som organisasjon (Crawford, 2008). Hvilke aktører og arbeidsoppgaver polisiær virksomhet fanger opp, har endret seg de siste årene, noe som har ført til at policing som konsept i større grad knyttes til arbeid og praksis, uten å fokusere på hvilke aktører som utøver den (Larsson \& Gundhus, 2007: 11). De siste årene har man sett at mindre tradisjonelle polisiære aktører blir objekt for studier innenfor konteksten av policing (Crawford, 2006; Jones \& Newburn, 2006; Rowe, 2008; Lomell, 2014; Nøkleberg, 2016; van Stokkom \& Terpstra, 2018). Denne inkluderingen betegnes gjerne som pluralisert policing, som henviser til at det finnes et mangfold av polisiære bidragsytere (Crawford mfl., 2005). Som arbeidsoppgave kan policing dermed utøves av en rekke aktører, både offentlige og private, men også profesjonelle og privatpersoner (Crawford, 2008).

Hvorvidt en arbeidsoppgave kan regnes som polisiær er ikke gitt, og definisjonen av policing består av en rekke elementer. Policing som arbeid kan sies å være målrettet, det utføres av flere ulike aktører i samsvar med normer og regler, i tillegg til at det tar sikte på å kontrollere omgivelsene nå eller i fremtiden (Crawford, 2008: 148). I sammenheng med kriminalitetsforebygging kan man dermed forstå polisiært arbeid som en rekke forebyggende handlinger. På denne måten kan det å utøve forebyggende oppgaver være avgjørende for om man regnes som utøver av polisiær virksomhet eller ikke, noe som gir rom for å studere både politi og arkitekters forebyggende arbeid innenfor et felles rammeverk.

\section{De kriminalitetsforebyggende logikkene gjennom arkitektur, design og fysiske omgivelser}

Med tanke på at politiet og arkitektene befinner seg innenfor forskjellige yrkesgrupper, vil det være naturlig at de har ulike roller i og forståelser av kriminalitetsforebyggende arbeid. Hvilke logikker som ligger til grunn, kan gjenkjennes i 
de forebyggende tiltakene, da ulike forståelser av kriminalitet kan identifiseres i strategiene som benyttes for å hindre den (Gundhus, 2014: 180). Forebyggende tiltak foregår på flere nivåer, hvor man på et nivå kan skille mellom formelle og uformelle strategier. Førstnevnte nivå er gjerne knyttet til mekaniske løsninger og organiserte aktørers bidrag, som synlig politi og kameraovervåkning (Jacobs, 1962; Crowe, 2000). De uformelle tiltakene knyttes gjerne til uformell sosial kontroll, som typisk foregår fremmede mennesker imellom (Jacobs, 1962). Disse tiltakene kan i tillegg betegnes som naturlige, fordi de ikke avhenger av formelle aktørers tilstedeværelse (Crowe, 2000).

Kriminalitetsforebyggende arbeid i offentlige rom har ikke utelukkende kriminalitetsreduksjon som mål, men kan også ha andre tiltenkte effekter. De ulike logikkene bør derfor ses i sammenheng med de bakenforliggende årsakene ved bruk av CPTED. Dette med tanke på at man i denne forebyggingsmodellen tar sikte på å hindre kriminalitet, samtidig som man forsøker å redusere publikums frykt for kriminalitet (Colquhoun, 2004; Aas mfl., 2010; Armitage, 2013). CPTED har dermed to overordnede formål - å (forsøke å) skape arkitektur som kan virke kriminalitetsforebyggende, i tillegg til å sørge for at bruken av rommene skal føre til reduksjon av kriminalitet og frykten for kriminalitet.

Frykt for kriminalitet bør ses i sammenheng med opplevelser av trygghet, da det henviser til publikums subjektive opplevelser. Å skape trygghet er ofte et av målene med forebyggende arbeid, og sosial kontroll gjerne er et viktig redskap i en slik prosess (Aas, mfl., 2010). Her er det dessuten vesentlig å skille mellom objektiv og subjektiv trygghet, som vil si faktisk versus opplevd trygghet (ibid.). Objektiv trygghet betegnes ofte som sikkerhet (Zedner, 2009).

Siden 90-tallet har forebygging i stor grad blitt knyttet opp til samfunnssikkerhet og beskyttelse (Gundhus, 2014: 184). Fokuset på sikkerhet har dermed blitt sentralt når man snakker om kriminalitetsforebygging, og kanskje spesielt gjennom situasjonelle tiltak i det offentlige rom. Dette handler særlig om at man utfører fysiske sikringstiltak på ulike steder for å forebygge kriminalitet (Zedner, 2009: 117; Bjørgo, 2011: 48). Sikkerhetstiltak rommer et bredt spekter, og strategiene kan være både symbolske og funksjonelle (Crawford, 2006: 117), mekaniske og organiserte (Crowe, 2000). Implementering av sikringstiltak i fysiske utforminger utføres gjerne på bakgrunn av et ønske om å redusere risiko (White \& Sutton, 1995).

Sikkerhet kan både forstås som et mål, og som en form for praksis (Zedner, 2009). Begrepet ses ofte i sammenheng med kriminalitet fordi lovbrudd kan bli definert som et spørsmål om sikkerhet (Kaufmann, 2018: 24). Det finnes flere tilnærminger til sikkerhetsbegrepet, men i en forebyggingskontekst forstås det først 
og fremst som en måte å tenke forebygging på. Dette på bakgrunn av at ulike tiltak og strategier gjerne bygger på en sikkerhetslogikk (Zedner, 2009: 7).

De ulike forebyggingslogikkene kan dermed deles opp i flere underkategorier, hvor en trygghets-, sikkerhets- og risikotankegang står sentralt. Med utgangspunkt i det teoretiske rammeverket kan hovedforskjellene sies å bestå i at trygghetslogikken henviser til publikums opplevelser, sikkerhetsperspektivet vektlegger fysiske sikringstiltak, mens risikologikken henviser til hvilke farer man står overfor og hvor sannsynlig det er at den inntreffer.

\section{Metode - datainnsamling og empiri}

Denne artikkelen er basert på intervjuer med politi og arkitekter, hvor hovedfokuset var rettet mot deres roller, tiltak og formål i det forebyggende arbeidet i offentlige rom. Interessen for deres kunnskap, tanker og tilnærminger rundt dette arbeidet er årsaken til at aktører innenfor disse yrkene ble aktuelle intervjupersoner. Dette først og fremst på bakgrunn av at de, som aktører innenfor disse yrkene, anses som den beste kilden til data som belyser disse elementene. Som grunnlag for det empiriske materialet ble det dermed utført totalt 16 intervjuer, med henholdsvis 8 politiutdannede og 8 arkitektudannede. Alle politiinformantene er tilknyttet en forebyggende enhet i politiet, mens arkitektene tilhører 6 ulike arkitektkontorer fordelt mellom to norske byer. Aldersspennet på informantene er mellom 28 og 64 år, hvorav 10 er menn og 6 er kvinner.

Kriminalitetsforebygging i offentlige rom er et felt som ikke er fullstendig etablert, hverken for norsk politi eller for arkitektene. Utvalget av informanter har vært strategisk (Thagaard, 2003), noe som var et bevisst valg for å komme i kontakt med relevante fagpersoner i yrkene som kunne besvare spørsmål om tematikken. I Norge finnes det ikke spesifikke organer innenfor politiet som utelukkende jobber med problemstillinger relatert til studiens tematikk. ${ }^{4}$ Til tross for det er informantene fra politiet tilknyttet en enhet som har forebygging som primæroppgave. På grunn av at aktørene innenfor denne enheten er de som i størst grad er involvert i slike type problemstillinger, ble politiinformantene rekruttert fra denne enheten.

4. Det er flere land som har egne særorganer eller spesialiserte grupper i politiet som får opplæring i CPTED, og som utelukkende jobber med en slik form for forebygging, eksempelvis England og Canada (Brantingham \& Brantingham, 1990; Crowe, 2000; Reynald \& Elffers, 2009). 
Om arkitektene var aktuelle som informanter var avhengig av at de oppga selv om de hadde kunnskap om prosesser hvor forebygging er inkludert, da spesielt med tanke på at dette ikke er et felt majoriteten av arkitekter jobber med. Strategien ble dermed å finne arkitekter som jobbet med offentlige rom, utearealer og byutvikling, for så å kontakte dem, fortelle litt om prosjektet og spørre om deltakelse. Siden dette er et lite felt med få aktører som arbeider på denne måten, ble det ansett som den mest gunstige metoden for å snakke med relevante informanter.

Intervjuene ble utført i 2018 og varte i gjennomsnitt en time. Formen på intervjuene var semi-strukturerte, og spørsmålene i intervjuguiden var i stor grad sentrert rundt aktørenes arbeidsoppgaver. Intervjuguiden var delt opp i seks adskilte kategorier, hvor temaene blant annet omhandlet virkemidler, formål, lovverk og roller. Alle intervjuene ble tatt opp, med samtykke fra informanten, og transkribert i etterkant. De som ønsket å godkjenne sitatene som ble brukt, gjorde det, med formål om å øke datakvaliteten og ivareta etiske hensyn.

Utgangspunktet for kodingen av materialet ble utført med en blanding av både teoristyrt og empiristyrt tilnærming til dataene. Dette med tanke på at enkelte av kategoriene ble utviklet med utgangspunkt i noen analytiske begreper og teoretiske perspektiver fra start av (Thagaard, 2003; Glaser \& Strauss, 2008), mens andre hadde sitt utspring fra empirien. Eksempler på analytiske begreper som ble plassert innunder disse kategoriene på forhånd er temaer som trygghet, sikkerhet og kontroll, mens ulike tankesett i det forebyggende arbeidet kom frem av empirien. Analysen kan derav regnes som tematisk, som går ut på å identifisere mønstre etter ulike temaer i dataene (Braun \& Clarke, 2006). Gjennom en kombinasjon av teori- og empiristyrt analyse kan funnene forstås i sammenheng med tidligere forskning og teoretiske forståelser av tematikken, samtidig som empirien har gitt rom for å oppdage nye mønstre.

\section{Analyse - Uformelle tiltak, gode steder og trygghetsskapende arbeid}

De ulike forebyggingslogikkene kommer både direkte og indirekte til uttrykk gjennom informantenes forståelser av kriminalitetsforebyggende arbeid og tiltak. I empirien fremkommer det at et viktig tiltak for forebygging $\mathrm{i}$ offentlige rom er å sørge for en jevn flyt av mennesker. En slik strategi for forebygging henviser altså til at brukerne av rommet blir et slags forebyggende element, gjennom tilstedeværelse i det aktuelle området. Dette fremkommer som et av elementene arkitektene tar i betraktning når de jobber med fysisk planlegging. En av arkitektinformantene (1) forteller: 
«Det vi setter fokus på er da den fysiske planleggingen, hvordan organiserer du rommet, sånn at på en måte de gode sosiale kreftene i byen er med å skape trygghet. Det går veldig mye på, på en måte en sosial overvåkning».

En sosial overvåkning kan forstås som en måte å tilrettelegge for kontroll på (Cohen \& Felson, 1979). De sosiale kreftene og den sosiale overvåkningen, kan forstås som et uformelt og naturlig virkemiddel i det forebyggende arbeidet. Samtidig omtales disse virkemidlene som en måte å skape trygghet på. Områder uten tilstedeværelse av folk oppleves gjerne som utrygt for publikum (Aas mfl., 2010: 76). Tilstedeværelse i seg selv kan derfor virke trygghetsskapende.

Et fokus på opplevd trygghet er dessuten noe som fremkommer i politiets forestillinger om kriminalitetsforebyggende arbeid i offentlige rom, blant annet sier en politiinformant (2) at et av formålene med fysisk planlegging er:

«Jeg håper at de bymiljøene som vi er involvert i, og som vi jobber aktivt med, så vil vi kunne se en reduksjon av kriminalitet. Men det jeg håper aller mest der er at folk opplever en økt trygghet».

Sitatet illustrerer at man kan skille mellom kriminalitetsreduksjon og trygghetsskapende arbeid. Selv om begge aktører fremhever trygghet som en viktig del av forebyggende arbeid, viser informantens beskrivelse at politiet i større grad trekker frem den faktiske kriminalitetsreduksjonen som et mål. På den måten kan man se forskjell i arkitektenes og politiets tankesett, da arkitektene ikke nødvendigvis anser kriminalitetsreduksjon som en del av sitt arbeid, dette er en av arkitektene (3) eksplisitt på:

«Vi har aldri snakket om at 'nå skal vi gå inn i et prosjekt og senke kriminaliteten', vi bare prøver å lage gode steder også er det tilfeldigvis, ja det er mye gjengproblematikk der eller det er salg av narkotika. Vi går ikke inn og sier sånn 'hva skal vi gjøre for at det ikke skal vare salg av narkotika her', men vi bare snakker generelt om 'hvordan kan vi gjøre det her til et bedre sted'».

På denne måten kan reduksjon av kriminalitet forstås som en indirekte del av arkitektenes forebyggende arbeid, når fokuset i større grad går ut på å tilføye området noe av positiv karakter. Dette med tanke på at de gode sosiale kreftene og et forsøk på å gjøre områder til bedre steder fremmes som forebyggende elementer. Ser man trygghetsskapende arbeid og den jevne flyten av mennesker som fordelaktig, forankres strategiene i å tilføye et positivt bidrag til rommet for publikum, noe det er tenkt at brukerne skal være hovedaktør i selv. 


\section{Ansvarliggjøring av borgerne og reduksjon av formelle tiltak?}

Når en jevn flyt av mennesker og trygghetsskapende tiltak er i fokus, innebærer det at brukerne av rommet blir sentrale brikker i den kriminalitetsforebyggende strategien. På bakgrunn av det, kan det hevdes at informantene tillegger publikums bidrag en stor betydning. Ser man dette i sammenheng med sitatene som fremmer at trygghet blant publikum skal styrkes, indikerer det at de må skape den selv. En informant fra politiet (2) sier at:

«Jo høyere opplevd trygghet det mindre kriminalitet er det. Men dette kan folk skape selv».

På denne måten ansvarliggjøres aktører utenfor politiet, dersom folk forstås som brukere av rommet. I lys av policing kan dette minne om en strategi hvor vanlige borgere blir oppfordret til å ta del i polisiær virksomhet (Bayley \& Shearing, 1996: 588), noe som dessuten illustrerer at det ikke utelukkende er politiets ansvar å forebygge kriminalitet. Samtidig kan det ses i sammenheng med tendensen om at publikum i større grad blir bedt om å ta ansvar for sin egen trygghet (Lomell, 2014: 259). Dette er noe som kan tenkes å påvirke forståelsen og bruken av andre tiltak for forebygging - hvis folk kan ta ansvar for forebygging selv, kan det tenkes å redusere behovet for andre, mer formelle strategier.

Politiets tilstedeværelse i det offentlige rom er en annen måte å implementere kontroll i et område på (Cohen \& Felson, 1979; Crowe, 2000). Til tross for at informantene vektlegger ønsket om at publikum skal utgjøre en trygghetsskapende funksjon i offentlige rom, anerkjennes dessuten synlig politi som et mulig tiltak for forebygging. Dette kommer frem når en av politiinformantene (9) viser til at:

«Tilstedevarelse er alltid viktig, uansett hva slags kriminalitet det er, at det er politifolk som er tilgjengelig og som er synlige, så forebygger du nesten uansett hva slags kriminalitet det er snakk om».

Selv om det kan være hensiktsmessig for kriminalitetsnivå, er det ikke nødvendigvis gitt at det har en positiv effekt på publikums opplevelsene av trygghet, ifølge en annen politiinformant (6):

«Dessverre så er det ikke sånn at nødvendigvis synlig politi alltid skaper trygghet, noen vil si: 'åh, hva har skjedd nå, det er synlig politi’, fordi vi ikke har vart så, eller er så synlig tilstede da med uniformer der folk ferdes».

Det kan stilles spørsmål ved hvilken effekt en jevn flyt av mennesker og synlig politi vil ha i praksis, og om de erstatter eller utfyller hverandre. Enkelte vil si at 
store folkemengder kan ha både positiv og negativ innflytelse på kriminaliteten $\mathrm{i}$ et område (Armitage, 2017: 239), mens andre har sett at uforventet synlig politi kan skape utrygghet (Aas, mfl., 2010: 72). Det er altså vanskelig å forutse hvilken faktisk effekt de ulike tiltakene har, og hvilke forebyggingsstrategi som iverksettes kan på denne måten avhenge av aktørens oppfatning av tiltaket som positivt eller negativt.

Tilstedeværelse fra politiet er likevel ikke det eneste formelle tiltaket som kan iverksettes, lignende kan mekaniske strategier benyttes. Kameraovervåkning er et eksempel på en strategi som har blitt brukt som et forebyggende redskap, men den er ikke nødvendigvis foretrukket av den grunn. Et noe kritisk syn på det mekaniske tiltaket fremkommer i det en av arkitektene (5) sier at:

«Det er jo ikke sikkert det er dumt å ha noen sånne overvåkningskameraer av og til, man må bare gjøre det med forstand og innen liksom. Vaere veldig oppmerksom på når det begynner å ødelegge. Når de tiltakene begynner å ødelegge tillitsbyggingen».

I slike tilfeller kan tankesettet bygge på en forestilling om uformell kontroll er den mest gunstige formen for overvåkning, på bakgrunn av at de andre formene får større negative konsekvenser. En slik forståelse skisserer dessuten et av hovedpoengene med primærkontroll som foretrukne metode for å kontrollere (Christie, 1982: 30). Denne foretrekkes fordi man i større grad føler en nærhet til hverandre dersom kontrollen er av uformell karakter, noe som kan skape tillit menneskene imellom og dermed øke tryggheten i område (ibid.).

\section{Sikkerhetsperspektivet}

Et fokus på brukerne kan potensielt redusere ønsket om å bruke formelle tiltak, som vil si at synlig politi, overvåkningskameraer og andre mekaniske løsninger får mindre oppmerksomhet (Crowe, 2000). Til tross for dette er ikke den objektive sikkerheten glemt av den grunn, men forståelsene av hvor nødvendig den er, er nyansert.

Sikkerhetstiltak fremmes gjerne som et svar på potensielle farer man står overfor, og består ofte av fysiske og symbolske konstruksjoner på initiativ fra formelle aktører (Crowe, 2000; Zedner, 2009). Sikkerhet knyttes gjerne opp til trussel og risiko (Engen mfl., 2016), og kan dermed forstås som en kontrast til trygghetsperspektivet. Behovet for sikkerhet kan se ut til å bli knyttet mot bestemte type farer, eller visse former for kriminalitet. Dette kommer frem i det en av politiinformantene (8) begrunner bruken av sikkerhetstiltak i offentlige rom opp mot trusselbildet: 
«(...) så ser jeg at offentlige rom blir kanskje viktigere og viktigere drevet frem av terrortrusselen, drevet frem av forskning, kanskje ikke så mye i Norge, men hvert fall andre steder. Og noe som er relativt greit å gripe fatt $i$, som kanskje ikke er så komplisert egentlig».

Selv om det er utfordrende å vurdere hvilke reelle trusler man står overfor, utgjør potensielle farer likevel en risiko flere ikke ønsker å ta (Zedner, 2009). Tankegangen om terrorsikring kan derfor fremstå som risikodrevet. Det kan likevel sies å være et skille mellom det å faktisk redusere risiko for terror, og det å bevare gode kvaliteter i bybildet. Dette kan illustreres ved det en av arkitektinformantene (5) poengterer:

«Den aller, aller laveste risikoen, er terrorisme, mens det å stanse liksom ødeleggelsene på Karl Johan det er, det regnes som så risikabelt at det kan vi ikke gjøre».

Informanten henviser til at til tross for at sannsynligheten for terror er liten, så er man likevel ikke villig til å ta sjansen på å bli utsatt for et potensielt angrep, noe som kan forstås som en kontrast til det politiinformanten (8) viser til. Ødeleggelsene på Karl Johan ${ }^{5}$ henviser til blomsterkasse som ble satt opp i 2017 som et sikkerhetstiltak, som er ment å fungere som en fysisk hindring mot potensielle terrorangrep. Tar man utgangspunkt $i$ at arkitektene anser uformelle tiltak som ideelle, indikerer sitatet at dette $i k k e$ gjenspeiles i byrommet. Å oppnå en tilstand av sikkerhet kan forstås å være verdt ødeleggelsene, noe som indikerer at det er en prioritering som må foretas. Årsakene til et slikt fokus kan være at man ser flere fordeler enn negative konsekvenser ved tiltak som styrker sikkerheten. En av politiinformantene (15) sier for eksempel at:

«Når vi i dag ser at, skjermer gågater eller torg eller sånne åpne rom ved å sette opp fysiske hindringer for å hindre biler $i$ å kjøre inn, så er det veldig mange som har fokus på at det er for å hindre noen $i$ å bruke en bil som en brannbukk eller kjøre inn for å skade folk. Det behøver ikke bare vare, å hindre en planlagt terrorhandling eller noe sånt no, vi har jo eksempler hvor personer har blitt syke fått illebefinnende og kjørt inn $i$ en folkemasse. Og det at vi må tenke kriminalitetsforebygging og sette opp fysiske avskjerminger, så vil vi også kunne forebygge uhell. Ja. Så at tiltak som i utgangspunktet er tenkt som et kriminalitetsforebyggende tiltak, det kan også virke dempende for, for ulykkerı.

På denne måten vil et sikkerhetstiltak også kunne ha flere potensielle funksjoner i det offentlige rom, på samme måte som at arkitektenes fokus på publikums opp-

5. Karl Johan er en hovedgate i Oslo sentrum. 
levelser kan ha flere positive effekter for områdene. En slik forståelse kan bidra til å forklare årsaken til at tiltak som er ment å redusere ulike skader får forrang, når disse tiltakene kan ha flere ønskede effekter - uavhengig av om det begrunnes i beskyttelse mot fysiske skader eller kriminalitet.

I lys av funnene vedrørende trygghetsaspektet kan det tyde på at fokuset på objektiv sikkerhet i praksis ser ut til å være større enn fokuset på den subjektive tryggheten. På den ene side kan kriminalitetsforebyggende tiltak i offentlige rom forstås å bygge på en tankegang om å oppnå en sikkerhetstilstand, mens på en annen side vektlegges trygghetsaspektet i større grad. Skillet mellom disse kan identifiseres i det en av arkitektene (16) forteller at:

«Det er ikke sånn at man, det er noen som sikrer og lager antiterrortiltak, som gjør spesifikt mot en type trussel, men innen, altså når det kommer til forebygging av kriminalitet så er det ikke like.. klart på en måte at det tiltaket gjøres mot kriminalitet og samtidig så er det jo enn for eksempel terrortiltak gjør at, vil jeg si, det er min mening, det minsker jo mange andre kvaliteter. Mens man kan kanskje håpe at et kriminalitetsforebyggende tiltak ikke gjør det».

Igjen fremheves sikkerhet som en førsteprioritet, dersom man tolker de kriminalitetsforebyggende tiltakene som de trygghetsskapende, og antiterrortiltak som sikkerhetstiltak. Denne fremstillingen underbygger dermed at trygghetsskapende tiltak, og dermed gjerne de uformelle tiltakene, er å foretrekke hos arkitektene. Slike preferanser nyanserer sikkerhetslogikken, da man på en side kan forstå sikkerhet som nødvendig, mens det på den andre siden ser ut til at for stor bruk av sikkerhetsstrategier kan medføre noen ulemper. På denne måten kan sikkerhetstiltakene få konsekvenser for det trygghetsskapende, som informantene i utgangspunktet fremmer som ideelt. De kontrastfylte logikkene kan på den måten resultere $\mathrm{i}$ et motstridende arbeid på det kriminalitetsforebyggende feltet $\mathrm{i}$ offentlige rom.

\section{Diskusjon - ulike logikker}

Analysen viser at logikkene som kan identifiseres i kriminalitetsforebyggende arbeid er ulike blant informantene, både på individuelt nivå, og mellom yrkesgruppene. Funnene rundt informantenes forebyggingslogikker kan plasseres i gråsonen mellom risiko, sikkerhets- og trygghetstilnærminger til forebygging.

Et tungtveiende fokus på sikkerhet har preget både forskningen og offentlige rom i flere år (Zedner, 2009; Engen mfl., 2016). Informantenes forståelser viser at det finnes ulike måter å tenke kriminalitetsforebygging på, og at man finner ytterpunktene ved å sette de uformelle og formelle tiltakene opp mot hverandre, hvor 
trygghetsskapende tiltak kan plasseres i den ene enden, og sikkerhetstiltak kan plasseres i den andre. Arkitektene ser ut til å stille seg kritiske til hvor stor vekt disse virkemidlene $b ø r$ ha, sammenlignet med politiet. Til tross for at begge yrkesgrupper fremmer naturlige, uformelle tiltak som ideelle, er det altså en forskjell i hvor nødvendig de synes at bruk av sikkerhetstiltak er. De kontrastfylte logikkene illustreres altså i gråsonen mellom subjektiv og objektiv kriminalitetsforebygging.

Spenningene mellom en objektiv og subjektiv tilstand av sikkerhet er ikke et nytt fenomen (Zedner, 2009). Hvilke funksjoner kriminalitetsforebyggende tiltak er tenkt derimot, i lys av trygghet- og sikkerhetstiltak, gir indikasjoner på hvilke prioriteringer som potensielt kan være førende for forebyggende praksis. Både trygghet og sikkerhet forstås som viktige verdier i samfunnet, og det kan sies at man er avhengig av et samarbeidsprosjekt mellom flere aktører for å sørge for en tilstand av begge (Zedner, 2009; White \& Gill, 2013). I denne sammenhengen er det både private og offentlige bidragsytere, med et tiltenkt bidrag fra publikum, som utfører det kriminalitetsforebyggende arbeidet. At dette er en arena hvor flere involveres kan være et resultat av et kollektivt ønske om å oppnå tilstander av både trygghet og sikkerhet.

Forståelsene av uformelle og formelle strategier, samt trygghet og sikkerhetsskapende arbeid, viser dessuten hvordan man kan stille spørsmål ved ansvarsfordeling mellom offentlige og private aktører, som er et tema som har blitt belyst innenfor policing-litteraturen (Bayley \& Shearing, 1996; 2001; 2005; Crawford mfl., 2005; Loader \& Walker, 2007; White \& Gill, 2013). Av enkelte hevdes det at inntoget av nye policing-aktører, spesielt private, har utfordret ideen om et offentlig gode. Eksempelvis har det blitt argumentert for at «goder» som blir begrenset til bestemte områder, kan være en konsekvens av pluraliseringen generelt og privatiseringen spesielt (Crawford, 2006). Et sentralt spørsmål som kan reises $\mathrm{i}$ den forbindelse er hva som er arkitektenes motivasjon for å involvere seg det $\mathrm{i}$ kriminalitetsforebyggende arbeidet. Det synes å kunne relateres til tre ulike aspekter.

Først og fremst kan det være en effekt av lovverket i form av Plan- og bygningsloven, som gjør at arkitektene blir pålagt å ta inn over seg forebyggende hensyn. Det kan imidlertid nevnes at det kan tyde på at lovverket ikke har like sterke føringer for arkitektene, slik som Politiloven har for politiet hva angår den forebyggende rollen. For det andre kan det tenkes at arkitektenes interesse henger tett sammen med et ønske om å skape profitt (White \& Gill, 2013), som potensielt realiseres ved å ha en utvidet interessefelt. For eksempel kan det tenkes at et kriminalitetsforebyggende fokus benyttes for å fremstå som mer attraktiv slik at 
nye og flere kunder benytter seg av dem. En tredje forklaring kan være at arkitektene har en genuin interesse $\mathrm{i}$ det å ivareta det offentlige gode, og at de trygghetsskapende strategiene de iverksetter er med på å sørge for det. Dersom en ser på hvilke beskrivelser som er presentert i denne studien, så synes denne å være mest plausibel. Ser man informantenes forståelser i lys av polisiær virksomhet, åpner det opp for at politi, arkitekter og publikum utgjør tre av potensielt mange bidragsytere på et felt som angår befolkningen. En slik trend underbygger dessuten hvordan man kan anse ulike aktører som forebyggere i ulike sammenhenger, noe som igjen er i tråd med den pluraliserte policingen og polisiære virksomheters fremvekst.

\section{Litteratur}

Aas, G., Runhovde, S., Strype, J., \& Bjørgo, T. (2010): Trygghet i det offentlige rom: i åtte norske kommuner og bydeler. Oslo: PHS Forskning 2010: 7.

Armitage, R. (2013): Crime Prevention through Housing Design: Policy and Practice. Basingstoke: Palgrave Macmillan. https://doi.org/10.1057/9781137316059

Armitage, R. (2017): «Design, crime and the built environment» i: Handbook of Crime Prevention and Community Safety. Red: Tilley, N. \& Sidebottom, A. Andre utgave. London: Routledge. https://doi.org/10.4324/9781315724393-11

Armitage, R. \& Monchuk, L. (2017): «What is CPTED? Reconnecting Theory with Application in the Words of Users and Abusers» i: Policing: A Journal of Policy and Practice. s. 1-19. https://doi.org/10.1093/police/pax004

Bayley, D.H. \& Shearing, C.D. (1996): «The Future of Policing» i: Law and Society Review, 30 (3). s. 585-606. https://doi.org/10.2307/3054129

Bayley, D.H. \& Shearing, C.D. (2001): The New Structure of Policing: Description, Conceptualization, and Research Agenda. Washington: National Institute of Justice.

Bayley, D.H. \& Shearing, C.D. (2005): «The Future of Policing» i: Policing Key Readings. Red: Newburn, T. New York: Routledge. s. 715-733.

Bjørgo, T. (2011): «Strategier for forebygging av terrorisme, del I» i: Forebygging av terrorisme og annen kriminalitet. Red: Bjørgo, T. Oslo: PHS Forskning 2011: 1.

Brantingham, P. \& Brantingham, P. (1990): «Situational crime prevention in practice» i: Canadian Journal of Criminology, 32 (1). s. 17-40.

Braun, V. \& Clarke, V. (2006): «Using thematic analysis in psychology» i: Qualitative Research in Psychology, 3 (2). s. 77-101. https://doi.org/10.1191/1478088706qp063oa

Burris, S.C. (2004): «Governance, Microgovernance and Health» i: Temple Law Review, 77. s. 335-362.

Carr, S., Francis, M., Rivlin, L.G. \& Stone, A.M. (1992): Public Space. Cambridge: Cambridge University Press.

Christie, N. (1982): Hvor tett et samfunn? Andre utgave. Oslo: Universitetsforlaget.

Clarke, R.V. (1980): «'Situational' Crime Prevention: Theory and Practice» i: British Journal of Criminology, 20 (2). s. 136-147. https://doi.org/10.1093/oxfordjournals.bjc.a047153 
Cohen, E.L. \& Felson, M. (1979): «Social Change and Crime Rate Trends: A Routine Activity Approach» i: American Sociological Review, 44 (4). s. 588-608. https://doi.org/10.2307/ 2094589

Colquhoun, I. (2004): Design Out Crime: Creating Safe and Sustainable Communities. Oxford: Architectural Press. https://doi.org/10.1057/palgrave.cpcs.8140201

Cozens, P.M. (2002): «Sustainable Urban Development and Crime Prevention Through Environmental Design for the British City. Towards an Effective Urban Environmentalism for the $21^{\text {st }}$ Century» i: Cities, 19 (2). s. 129-137. https://doi.org/10.1016/S0264-2751(02)00008-2

Crawford, A., Lister, S., Blackburn, S. \& Burnett, J. (2005): «Plural policing: The mixed economy of visible patrols in England and Wales» i: Researching Criminal Justice Series. Bristol: The Policy Press.

Crawford, A. (2006): «Policing and security as 'club goods': the new enclosures?» i: Democracy, Society and the Governance of Security. Red: Wood, J. \& Dupont, B. Cambridge: Cambridge University Press. s. 111-138. https://doi.org/10.1017/CBO9780511489358.007

Crawford, A. (2008): «Plural Policing in the UK: Policing Beyond the Police» i: Handbook of Policing. Red: Newburn, T. Cullompton: Willan Publishing. s. 147-181.

Crowe, T. (2000): Crime Prevention Through Environmental Design. Applications of Architectural Design and Space Management Concepts. Andre utgave. Boston: ButterworthHeinemann.

Egge, M. \& Barland, B. (2007): «Klarer forebyggingsfeltet seg uten politiet?» i: Polisiær virksomhet. Hva er det - hvem gjør det? Red: Gundhus, H.I.O., Larsson, P. \& Myhrer, T.G. Oslo: PHS Forskning 2007:7. s. 153-161.

Engen, O.A.H., Kruke, B.I., Lindøe, P.H., Olsen, K.H., Olsen, O.E. \& Pettersen, K.A. (2016): Perspektiver på samfunnssikkerhet. Oslo: Cappelen Damm Akademisk.

Ericson, R.V. \& Haggerty, K.D. (1997): Policing the risk society. Oxford: Clarendon Press.

Foucault, M. (1977-78): «Security, territory and population» i: Lectures at the College de France, 1977-78. s. 16-39.

Garland, D. (2001): The culture of control. Oxford: Oxford University Press.

Glaser, B.G. \& Strauss, A.L. (2008): The discovery of grounded theory: strategies for qualitative research. New Brunswick \& London: A Division of Transaction Publishers. Grönlund, B. \& Schock, L. (1999): «Den danske modellen» i: Den trygge byen. Kriminalitetsforebyggende planlegging. Red: Skouen, T. Oslo: Norsk Form. s. 29-48.

Gundhus, H.O.I. (2010): «Ekspertise eller dialog? Tillit og profesjonalisering av politiet» i: Tillit til politiet. Red: Runhovde, S.R. Oslo: PHS Forskningsserie 4: 2010. s. 141-162.

Gundhus, H.O.I. (2014): «Forebyggende politiarbeid» i: Innføring i politivitenskap. Red: P. Larsson, H.O.I. Gundhus og R. Granèr. Oslo: Cappelen Damm Akademisk. s. 178- 204.

Halvorsen, K. (2008): $\AA$ forske på samfunnet. En innføring i samfunnsvitenskapelig metode. Femte utgave. Oslo: Cappelen Damm.

Hansen Löfstrand, C. (2019): 'Marketization in a State-Centred Policing Context: The Case of Sweden'. European Journal of Criminology. DOI: 1477370819882905. https://doi.org/ $10.1177 / 1477370819882905$

Hvattum, M. (2015): Hva er arkitektur. Oslo: Universitetsforlaget.

Jacobs, J. (1962): The Death and Life of Great American Cities. London: Jonathan Cape. 
Jones, T. \& Newburn, T. (2006): «Understanding plural policing» i: Plural Policing: A comparative perspective. Red: Jones, T. \& Newburn, T. London: Routledge.

Kaufmann, M. (2018): «Kriminalitetskontroll eller sikkerhet?» i: Nytt norsk Tidsskrift. 35 (1). https://doi.org/10.18261/issn.1504-3053-2018-01-03

Kvale, S. \& Brinkmann, S. (2009): Det kvalitative forskningsintervju. Tredje utgave. Oslo: Gyldendal Akademisk.

Larsson, P. \& Gundhus, H.O. (2007): «Policing i et norsk perspektiv» i: Polisiær virksomhet. Hva er det - hvem gjør det? Red: Gundhus, H.O., Larsson, P. \& Myhrer, T.G. Oslo: PHS Forskning 2007: 7. s. 11-31.

Lie, E.M. (2011): I forkant. Første utgave. Oslo: Gyldendal akademisk.

Lomell, H.M. (2014): «Polisiær virksomhet utenfor politiet» i: Innføring i politivitenskap. Red: P. Larsson, H.O.I. Gundhus og R. Granèr. Oslo: Cappelen Damm Akademisk. s. 255-272.

Lundeberg, I.R. \& Mjåland, K. (2017): Åpne russcener i Bergen etter stengningen av Nygårdsparken: En studie av strategi, tiltak og brukererfaringer [rapport, sosiologi]. Bergen: Universitetet i Bergen.

Newman, O. (1972): Defensible Space: Crime Prevention Through Urban Design. New York: Macmillian.

Nøkleberg, M. (2016): «Security Governance - An Empirical Analysis of the Norwegian Context» i: Nordisk politiforskning, 3 (1). https://doi.org/10.18261/issn.1894-8693-2016-01-05

Plan- og bygningsloven (2010): Lov om planlegging og byggesaksbehandling av 27. juni 2008 nr. 71 .

Regjeringen (2015): Ny organisering for styrket kriminalitetsforebygging. [Internett]. 8. oktober 2015. Justis- og beredskapsdepartementet. Tilgjenglig fra: https:/www.regjeringen.no/no/ aktuelt/ny-organisering-for-styrket- kriminalitetsforebygging/id2457497/ [Lest: 09.05.19].

Reynald, D. \& Elffers, H. (2009): «The Future of Newman's Defensible Space Theory» i: European Journal of Criminology, 6 (1). s. 26-46. https://doi.org/10.1177/1477370808098103

Rowe, M. (2008): Introduction to policing. London: Sage publications.

Strudwick, K. Jameson, J. and Rowe, J. (2017): «Developing Volunteers in Policing: Assessing the Potential Volunteer Police Community Police Officer» i: Policing: A Journal of Policy and Practice. DOI: http://dx.doi.org/10.1093/police/pax056. https://doi.org/10.1093/police/ pax056

Sætre, M., Hofseth, C. \& Kjenn, B.L. (2018): Trender i kriminalitet 2018-2021: Digitale og glokale utfordringer. [rapport politiet]. Oslo: Oslo politidistrikt.

Thagaard, T. (2003): Systematikk og innlevelse - en innføring i kvalitative metode. Tredje utgave. Bergen: Fagbokforlaget.

Ugelvik, T. (2019): Sosial kontroll. Oslo: Universitetsforlaget.

Unstad, M. \& Christophersen, J. (1999): Bedre planlegging, færre farer. Kriminalitetsforebyggende sjekkliste for planleggere. Oslo: KRÅD.

van Steden, R. (2018): «Street pastors: on security, care and faith in the British night-time economy» i: European Journal of Criminology, 15 (4). s. 403-420. https://doi.org/10.1177/ 1477370817747499. PMid:30034294 PMCid:PMC6041764

van Stokkom, B. \& Terpstra, J. (2018): «Plural policing, the public good, and the constitutional state: an international comparison of Austria and Canada - Ontario» i: Policing and Society, 28 (4). s. 415-430. https://doi.org/10.1080/10439463.2016.1205065 
Wakefield, A. (2003): Selling Security: the private policing of public space. Cullompton: Willan Publishing.

White, A. \& Gill, M., (2013): «The Transformation of Policing From Ratios to Rationalities» i: British Journal of Criminology, 53 (1). s. 74-93. https://doi.org/10.1093/bjc/azs049

White, R. \& Sutton, A. (1995): «Crime prevention, urban space and social exclusion» i: ANZJS, 31 (1). s. 82-99. https://doi.org/10.1177/144078339503100106

Zedner, L. (2007): «Pre-Crime and post-criminology?» i: Theoretical Criminology, 11 (2). S. 261-281. https://doi.org/10.1177/1362480607075851

Zedner, L. (2009): Security. London: Routledge. https://doi.org/10.4324/9780203871133 